\title{
Building the Image of Semarang City through Motocross World Championship
}

\author{
http://dx.doi.org/10.25008/jkiski.v5i2.423 \\ Mahrani Mahrani ${ }^{1}$, Poppy Ruliana ${ }^{2 *}$, Rajab Ritonga ${ }^{3}$ \\ ${ }^{1,2}$ InterStudi Communication College \\ Jl. Wijaya II No. 62, Jakarta 12160 - Indonesia \\ ${ }^{3}$ Faculty of Communication Studies, LSPR Communication and Business Institute \\ Jl. K.H. Mas Mansur Kav. 35 Jakarta 10220 - Indonesia \\ "Correspondent author: mahrani.rani33@gmail.com
}

Submitted: November 03, 2020, Revised: December 09, 2020, Accepted: December 30, 2020

Accredited by Kemristekdikti No. 28/E/KPT/2019

\begin{abstract}
This research discusses how motocross world championship MXGP 2019 in Semarang City improved the image of the Indonesian tourism. This research also aims to see how the event has an effect on the motocross fan community in Semarang particularly to look at the development of sports tourism and future trend of sports tourism in Indonesia. This research uses qualitative approaches. Data were collected through a semi-structured interview technique to analyze motocross grand prix world championship 2019 held to improve the image of sport tourism. Key informant is Lightning Production as the organizer of the motocross grand prix world championship. The other informants are Youthstream, Semarang Mayor, Chief of the Indonesian Motorcycle Association and 10 spectators of Motocross MXGP World Championship 2019. The views of the informants were analyzed to yield findings and recommendations to develop the image of tourism in Indonesia, particularly Semarang City. The result of this research shows the Motocross Grand Prix World Championship 2019 could increase the image of sport tourism and give large contributions to the development of tourism in Semarang City.
\end{abstract}

Keywords: Building image; sport tourism; motocross grandprix; world championship; development of tourism

\section{Introduction}

Indonesia is the largest archipelagic state in the world, with 17,508 islands stretching from Sabang to Merauke. Geographically, Indonesia lies along the equator and between the Asian Continent and the Australian Continent and between the Pacific Ocean and Indian Ocean. Indonesia has a strategic position because it is located in the global traffic intersection. In addition, Indonesia also has diverse cultures, ethnic groups and languages and is endowed with beautiful nature, which serve as attractions for sport tourism (Irawan, 2019).

Sport tourism is one of the fastest growing sectors in the tourism industry. Many tourists are interested in sport event during their travel in tourist destination. Sport event attracts tourists particularly spectators since they can try authentic local experience. Mega sport events such as Olympiad and World Cup can serve as a tourism development catalys if they successfully benefit from destination branding, infrastructure development and other socio-economic advantages (UNWTO, 2020).

The Motocross Grand Prix (MXGP) world championship is one of sport tourism activities which is part of Wonderful Indonesia campaign as a substitute for the previous brand of Indonesian tourism; Visit Indonesia. The change in brand was 
aimed at strengthening the image of Indonesian tourism in the eyes of the world. Foreign tourists are not only invited to visit Indonesia but are also served with wonderful tourism of the country (an interview with the Semarang Mayor, October 9, 2020).

The Wonderful Indonesia brand is considered more attractive to portray Indonesia and is used as a means of introducing itself: to show that Indonesia has cultural characteristics which are not inferior to those of other big countries in Europe and America, including in organizing an international-scale sport event. Hence, the Motocross Grand Prix world championship offered a chance to promote Wonderful Indonesia.

The Motocross Grand Prix (MXGP) world championship in Indonesia is an international communication event because it was held following information exchange and diplomacy between Youthstream as MXGP license holder and Lightning Productions as promoter. The motocross world championship was held three years ago, thereafter, it has opened new world of motocross industry in Indonesia.

Motorcycle racing is not new for Indonesian youths. The trend of the sport is inseparable from the activities of urban and rural residents that use motorcycles in their daily life as a transportation means. On the other hand, riding motorcycles is the lifestyle of youths; making a tour of various cities by riding motorcycles together, or adventuring by riding motorcycles off road. That is the reason why local residents have great interests to watch the motocross world championship held in Indonesia. $\quad$ Spectators various cities in Indonesia have always made world championship more lively.

Foreign spectators also come to watch every motocross world championship held in Indonesia. Like football, motocross also has fanatic fans, though their number is smaller than that of football fans. Motocross fans flock to the venue of motocross to watch the motorcycle racing held on an enclosed off-road circuit specially designed with a certain level of difficulties.

For the first time ever, Indonesia hosted motocross world championship in Pangkal Pinang, Bangka Belitung in 2017. Indonesia again hosted the event in Pangkal Pinang and Semarang (Central Java) in 2018, and in Palembang (South Sumatra) and Semarang in 2019. The theme of the motocross world championship in Pangkal Pinang and Palembang is MXGP of Indonesia, and in Semarang is MXGP of Asia (interview with the Director of Lightning Production, on September 15, 2020).

The mega sport tourism event can serve as a tourism development catalyst if it is successfully used as a destination branding. Infrastructure development and economic benefit through multiplier effect will emerge by hosting motocross world championship. This is inseparable from the rapid and popular development of motocross sport in various countries. Various countries make endeavors to host the prestigious event which in 2019 was held in a series in 19 cities in the world (Table 1).

Table 1. Calendar of Motocross World Championship 2019

\begin{tabular}{|l|l|l|l|}
\hline \multicolumn{1}{|c|}{ Date } & Grandprix's Host & \multicolumn{1}{c|}{ Venue } & \multicolumn{1}{c|}{ Support Classes } \\
\hline 1 March & Argentina & Neuquen & - \\
\hline 24 March & Great Britain & Matterley Basin & EMX250 \& EMX 2t \\
\hline 31 March & The Netherlands & Valkenswaard & EMX125 \& Women \\
\hline 7 April & Italy & Pletramurata & EMX125 \& EMX 250 \\
\hline 1 May & China & Shanghai & - \\
\hline 12 May & Italy & Mantova & EMX 125 \& EMX 2t \\
\hline 19 May & Portugal & Agueda & EMX 2t \& Women \\
\hline 26 May & France & St Jeand'Angely & EMX125 \& EMX250 \\
\hline 9 June & Russia & Orlyonok & EMX250 \& EMX 2t \\
\hline 16 June & Latvia & Kegums & EMX250 \& EMX 2t \\
\hline 23 June & Germany & Teutchenthal & EMX125 \& EMX250 \\
\hline 7 July & Indonesia & Palembang & - \\
\hline 14 July & Indonesia & Semarang & - \\
\hline 28 July & Czech Republic & Loket & EMX65, EMX85, \& Women \\
\hline 4 August & Belgium & Lommel & EMX125 \& EMX250 \\
\hline 18 August & Italy & Imola & EMX 2t \& Women \\
\hline 25 August & Sweden & Uddevalla & EMX125 \& EMX250 \\
\hline 8 September & Turkey & Afyonkarahisar & EMX 2t \& Women \\
\hline 22 September & Hong Kong & Hong Kong & \\
\hline
\end{tabular}




\begin{tabular}{|l|l|l}
\hline 29 September & The Netherlands & Assen
\end{tabular}

Source: (Guide MXGP, 2019)

In the calendar, Indonesia was given a chance to hold the MXGP tournament in Palembang and Semarang in the same month but on different dates. Indonesia was chosen as the host of the event because according to the Infront Moto Racing CEO:

Indonesia is a very important country for motorsports in general and for the MXGP! We have a very important fan base in the country. For example, when it comes to social networks, Indonesia is our first country in terms of followers. Call it a few numbers, 1.6 million Indonesian fans love the MXGP Facebook page which creates massive engagement from the country, $96 \mathrm{~K}$ fans follow the MXGP Instagram page and the large traffic features and the MXGP-TV Youtube page become Indonesia the second country in terms of views, this time. For this reason, MXGP has also started producing and publishing certain content in Indonesian such as race posts on social networks, interviews and post-race highlight voice actors in every GP, ALL for Indonesian fans. Apart from that, the motorcycle market is very important for the manufacturers competing in the MXGP. Indonesians are very enthusiastic about motocross (an interview with David Luongo, October 11, 2020).

Although the motocross world championship 2019 was held in two cities, this research focuses on discussing the motocross tournament held in Semarang. This is because Semarang was chosen for the second time to organize the event. When Semarang organized MXGP (Motocross Grand Prix) on Bukit Semarang Baru Circuit for the first time in 2018, the city received The Best Performance world-class award from Youthstream.

The Semarang motocross circuit was also chosen as the world's second best circuit for combining the world circuit standard and reforestation in the circuit (Figure 1). The other reason behind the selection of Semarang as the site of research subject is that the city is the embryo of Indonesian Motor Association (IMI) (an interview with the Director of Lightning Production, September 15, 2020).
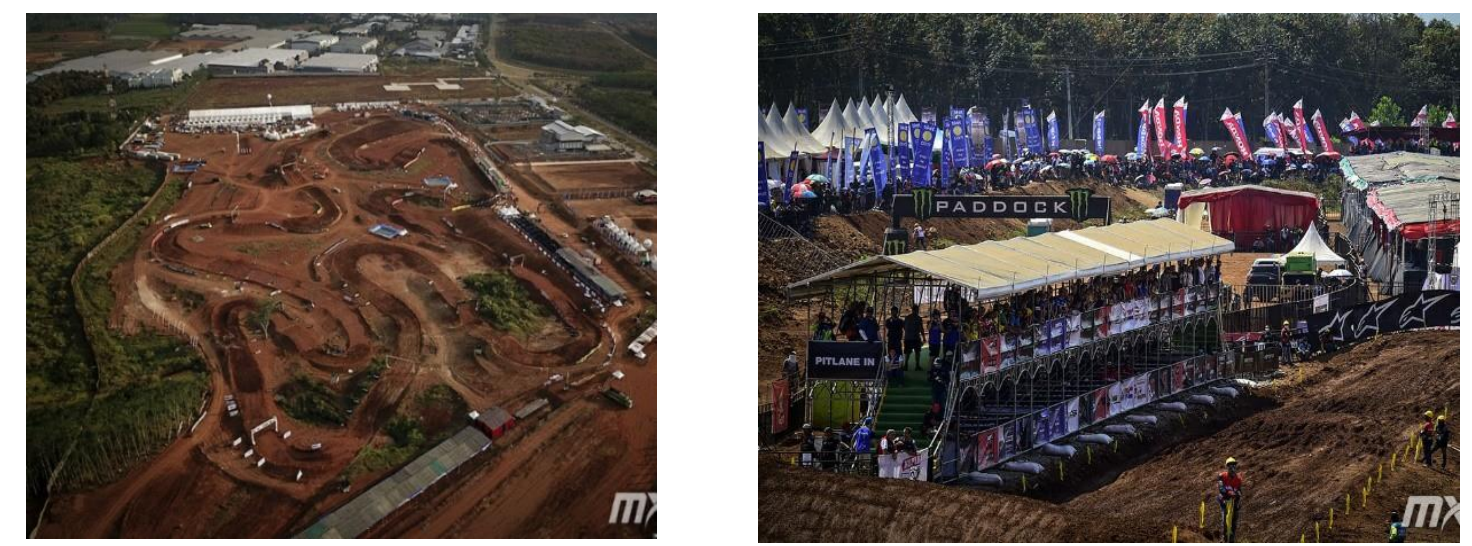

Figure 1: Bukit Semarang Baru Circuit Source : Official MXGP, 2019

The characteristics of the circuit in Semarang was quite challenging for world-class riders. It is the only circuit with gradient jumping. World riders are fond of a challenging circuit (Mico, 2019). The motocross circuit in Semarang covers 30 hectares, with a circuit length of $1.7 \mathrm{~m} 2$, and a track width of 12 meters to 27 meters, while straight track covers 100 meters. There are 20 handicaps, including two double jumps, two triple jumps, camel track and several other variants. The track is very spectacular. The Semarang circuit is the best motocross circuit in Indonesia and Asia (an interview with DT racer, October 9, 2020).

As many as 36 world racers from France, the Nederlands, Australia, Italy, Spain, Germany, and Austria took part in the tournament. Four Indonesian racers under the name Red-and-White Team participated in the event held from July 12 to 14, 2019.

The competition was held in various categories, MXGP and MX2 classes, veteran racing, and national racing. MXGP world championship is the highest category. Indonesia 
has Motocross \& Grasstrack community with an estimated 4,330 racers. The community has produced many national racers. Automotive fans in Central Java are quite fanatic. Semarang which is located in the central part of Indonesia can easily be reached from various cities in the country.

Several noted Indonesian motocross athletes based on their seeded achievements and the Central IMI's evaluation can take part in the MXGP event according to the number of wild cards issued by FIM and Youthstream (World Promotor-MXGP). The step is aimed to improve crossers' skill and mechanic teams' capability, as well as to create local heroes in the MXGP event in Indonesia as the host. It also serves as a yardstick of Indonesian crossers/teams' progress (an interview with IMI Chief, September 30, 2020).

The holding of MXGP world championship faces obstacles as stated by the Director of Lightning Production. The obstacles include a lack of sponsors, the central government's supports, training for the racing committee, changing weather, and a lack of international flight routes from and to Semarang (an interview, September $15,2020)$.

The Semarang Mayor stated that Motocross MXGP world championship 2019 is an international scale event which needs very complex coordination with various parties" (an interview, October 9, 2020).

The public is convinced that the use of large sport tourism event as tourism business and marketing communication will contribute to the success of tourist destination in the future by creating awareness, improving image and giving contributions in the economic, social and cultural fields in the future (Dongfeng, 2013).

Sport events held in various types and sizes attract both domestic and foreign tourists. Participants or spectators try to add local taste to make a distinction and give local experience which can eventually influence the perception and image of destination. Yet, the result of research, questions the use of large sport event as a means of improving image and marketing destination to domestic and foreign tourists. Awareness of international sport event will have a positive impact on the atmosphere and image of destination services as well as the image of tourist destination as a whole. Exploring the impact of the initiative of large sport event as a whole on the image of host city from foreign tourists' perspective is, in general, important (Cevik Huseyin and Kerem Yildurum Simsek, 2020).

The other findings of research disclose that the feature of core product and the identification of sport fans are significantly related to the wish of international spectators to attend a similar event in the future and visit again the country; whereas the quality of the event's operation is only found to have a significant impact on patronage, and the image of destination only has a significant impact on the wish to stay (Hua et al., 2019).

The findings of this research highlight the importance of relevant concepts to attract, serve, and maintain international visitors in the event. Unlike other studies that focus on game and event, this study expands larger spectrum around Formula One (F1) event and systematically, evaluates the concept and important factors influencing international tourists to attend the event, which may serve as a quite large economic source. This finding provides empiric evidence for tourism event and management and marketing (Watanabe et al., 2018).

The research conducted by (Qu et al., 2011) shows the unique image as new component of the destination branding association. It is proposed that the entire image of destination including branding image is a mediator between its branding association (namely, cognitive, affective and unique image components) and the behavior of tourists in the future, namely intention to visit again the country and give recommendations to it. This affirms that the entire image is influenced by three types of branding association which serve as an important mediator between the branding association and tourist behavior in the future. In addition, unique image has the second largest impact on the entire process of forming pictures after cognitive evaluation.

Several previous researches provide explanations in several views. The other example is provided by Pike \& Ryan (2004) that state that the image of destination is considered to be an element related to cognitive image, affective goal and overall image (Pike \& Ryan, 2004).

\section{Theoretical Frameworks}

Goeldner \& Ritchie (2005) defined tourism as efforts, activities and outcomes arising from the interactions among host governments, tourism suppliers, tourists and surrounding environments involved in the attracting of visitors to tourist sites. Sport and tourism are two kinds of activities that can be united and have a double effect on economic development. Hence, sport tourism draws attention from various parties: government, private party, sport industry, tourism industry, academics and community (Goeldner \& Ritchie, 2005).

Sport Tourism is a new perspective in Indonesia, namely tourist attractions that can build multicultural tourism. Tourist attractions are all forms of activities that have typical characteristics, 
aesthetics or beauty, diversities, natural wealth, cultures and man-made objects that become the destination of tourist visits. Tourist attractions are anything found in tourist destinations to make people interested in visiting the tourist destination (Astuti, 2015).

According to Spillane (1987), sport tourism is categorized into: (1) big sport event that is big sport events such as Olympic Games, World Cup, world boxing tournament and other sport events that attract not only relevant athletes but thousands of spectators or fans as well, and (2) Sporting Tourism of the Practicioners that is sport events for those wishing to get training and practice the sports such climbing, horse riding, fishing and so on (Astuti, 2015).

In tourism system, many actors play a role in driving the system. The actors are tourism workers in various sectors. In general, tourism is classified into three pillars, (1) community, (2) private group, (3) government. Community are those residing in tourist destinations as owners of various resources as tourism assets, such as culture. The community include social figures, intellectuals, NGOs, and mass media.

Private group is the association of tourism businesses and businessmen, while government group is various administrative territories, starting from central government, provincial government, district government, sub-district government and so on. The operation of tourism system can run properly if the components fuse into one and mutual tourism activity.

Sport Tourism needs reliable or competent human resources to design various kinds of sport activities to make them saleable tourist attractions because they hold economic values and bring about benefit to state or regions. The development of sport tourism in Indonesia is in demand so that it must take into account supply when demand is on the rise.

\section{City Image}

Tourism image, according to Pitana and Diarta (2009), is tourists' confidence in products and services in tourist destinations. Destination image is not always formed from experience or fact but it can also be formed so that it serves as strong motivation to make a journey to tourist destination (Pratiwi et al., 2018).

Destination image based on tourists' assessment can differ from one another. According to Lopes, the concept of tourist destination image is the expression of all objective knowledge, presumption, imagination and emotional thought of an individual or a group of individuals about certain location (Hanif et al. 2016). Kotler and
Haider defined image as the number of all confidences, ideas and impressions that someone is related to tourist destination (Pike \& Ryan, 2004). City image is generally referred to whole impression created in the mind of various target groups. This covers physical attributes of city, service, attraction, name, logo, reputation, and benefit given to target group. City image can be improved or changed; and the use of various marketing communication strategies for marketer to intentionally form, improve or change city image, often known as city branding (Liu \& Gratton, 2010). Simon Anholt in Moilanen and Rainisto (2009) stated that image is the act of managing the direction or objective of using tactical ideas or innovations and organizing the principles of economy benefiting the community and government (Moilanen \& Rainisto, 2009).

City image is not merely a motto but it is important to complete it with professional tourism management. Domestic tourism operators are very important, play a role and take active part in promoting global tourism image (Sunarto, 2020). Competition among countries to create positive image to attract important stakeholders, including consumers, investors and tourists has increasingly become tighter (Liu \& Gratton, 2010).

The effect of image on the process of selecting destinations has been studied by many experts (Chi \& Qu, 2008) and has been widely recognized that image can influence perception, choice, attitude and satisfaction of customers, investors or visitors (Castro et al, 2007; Jenkins, 1999; Milman \& Pizam, 1995; Echtner \& Ritchie, 1991 in Donngfeng, 2013). Liu and Gratton (2010) affirmed that all image factors are the prediction of intention to visit again the destination.

Awareness of sport event may have a positive effect on the atmosphere and service image of tourist destination, as well as the image of tourist destination as a whole. The result shows that city marketers must segment sport tourists from general tourists and apply different marketing strategies (Liu \& Gratton, 2010).

\section{Motocross Grand Prix (MXGP)}

Motocross is a motorcycle race over rocky and muddy terrain consisting of artificial hurdles and mounds to be jumped by crossers. Motocross circuit layout also uses landscape for a change in elevation, terrain and typical features. Motocross is the form of motorcycle sport or vehicle race over all kinds of terrain on closed or open off-road circuit.

Motocross riders put more emphasis on skill and physical fitness than on motorcycle performance as most other sport racers do. Of course, motorcycle 
setup is adjusted to the racing style of riders with very important handling and suspension to achieve outcome in a Grand Prix. After all, the greatest factors rest with technique, physical condition and mental strength of riders.

Motocross world championship is a cross country tournament held on a circuit using hurdles and special vehicles, special engine adjusted to the Federation International Motocross rules. MXGP is the most elite motocross event in the world. Like MotoGP, this event is also under the aegis of FIM (Fédération Internationale de Motocyclisme). The world motocross series which was held for the first time in 1957 is quite old. As comparison, the first MotoGP racing was held eight years earlier (Youthstream, 2019).

\section{Material and Methodology}

This research is framed in interpretative paradigm with qualitative approaches, while the research method used is descriptive to portray a reality in order that it could be understood as a whole. In this context, the researcher adopts the concept of Quivy and Campenhoudt (2008) who stated that theoretical approaches are used to overcome problems and interrogate phenomena that are studied, and construct problems, which means answering the question of how to approach phenomenon, Shipway shows the use of qualitative method to produce a report of sport tourists' experience in participating sport tourism while holidaying (Martins, 2015).

Meanwhile, Shipway and Jones (2007) stated to understand the social world of sport tourism, qualitative research is more accurate than other research approaches such as conceptualizing sport tourism with variables and relations among them (Gibson et al., 2018). Hence, the core question of this study is what picture arises from our thoughts about city image motocross MXGP world championship 2019 in Semarang City as a tourist destination area.

Key informant in this research is the Director of Lightning Production as the promoter of MXGP world championship in Indonesia. To balance the information obtained from the key informant, other informant, namely the Semarang Mayor as a policy holder, is needed. The other informants are the Chief of Indonesian Motor Association (IMI), Youthstream as an official promotor of the MXGP world championship, and 10 spectators of MXGP world championship comprising five foreign tourists and five domestic tourists.

Data analysis is conducted through display, reduction and verification phases before research conclusion is made, while data collection technique uses indirect deep interviews using email, Zoom and Google Form. This technique is used since it is impossible to conduct direct interviews amidst large-scale social restrictions to avert the spread of Covid-19.

\section{Result and Discussion}

The implication of motocross MXGP world championship of Asia organized by Lightning Production in collaboration with Youtstream is a stimulus from outside the organization that can affect audience's response. Lightning Production is a company that is engaged as an event organizer and experienced in organizing national and international racing tournaments.

The vision of organizing MXGP tournament of Asia is to show the world that Indonesia is able to organize a world-class event. In addition, it also aims to make Indonesia one of the world's automotive tournament destinations, promote automotive tourism and give home training experience to national racers to become prominent ones.

Meanwhile, the mission is to: (1) cooperate professionaly with Youthstream as a MXGP license holder; (2) cooperate with the government; (3) groom national racers to make Indonesia wellknown at international level; and (4) make IMI a forum of automotive activities in Indonesia (key informant JD). To realize the vision and mission in organizing the international class auto racing, Lightning Production needs good communication planning to ensure that the world tournament will run smoothly and successfully. Informant JD (key informant, 2020) stated communication planning is realized through the following stages after securing a contract:

First stage, conducting comparative studies in several countries to see how to design a venue of MXGP event, in addition to visiting the local authorities to see how to lobby the government of the city where the tournament will be held. Second stage, setting up a Racing Committee that will implement all FIM (Federation Internationale de Motorcyclisme) rules, ranging from surveying location, designing the circuit, training human resources on the circuit, to setting up a medical team in the field. Third stage, setting up Organizing Committee to help all pre-event activities until the event is held. The last stage is coordinating with the international organizer (Youthstream) for the transfer of knowledge about the planning and realization of the event.

The planning made by Lightning Production and the Semarang City Government is considered professional as stated by foreign tourist informants (Informants SN, WV and AW, BR and DW): 
The most professional organization ever. I have seen a lot of Motocross Grand Prix and MXGP since 1972 almost 50 years in the Industry. The planning was complete and the whole organization was very well done. Great hospitality hosts and very friendly staff. Tim's incredible receptions, banquets and introductions are the best in the world.

He went on to say: I didn't expect they could provide such a great experience with just two days of events. The hotel, venue and parking lot are huge.

Based on the communication planning, the preparations made by Lightning Production to find information and data pertaining to motocross world championships in other countries have been on the right track so that the tournament was held in accordance with FIM rules applied without exception. The communication planning made by Lightning Production in collaboration with the Semarang City Government, and IMI has also been on the right track.

IMI, as the motorcycle sport facilitator and regulator in Indonesia, appointed its association member as the national/international promotor of national \& international tournament (an interview with the Chief of IMI Central Executive Board, September 30, 2020). It is believed that these factors are important for planning a motorcycle sport event. This is quite relevant to understand in a complex economic environment dominated by tourism industry, and to face very competitive alternatives in the area, with the city offering a variety of alternative tourism products and events (Couto et al., 2017).

Lightning Production, as the event organizer, also provided various forms of amusements for motocross spectators while the event was going on. The additional amusements added to the entire values of the event and motivated spectators to attend the event since tourists or spectators that have positive memory about the previous experience indicate strong value loyalty (Jin et al., 2013).

Physical environment is another factor that needs to be considered by the event manager. Lightning Production put additional amusements during the event as an important strategy by featuring noted artists and displaying cultural dances during the opening ceremony of MXGP 2019 to support sport tourism, by highlighting acculturation and harmony of cultures developing in Semarang City, such as Javanese, Arabic, Chinese and Dutch cultures (an interview with HN, October 9, 2020) (Figure 2).

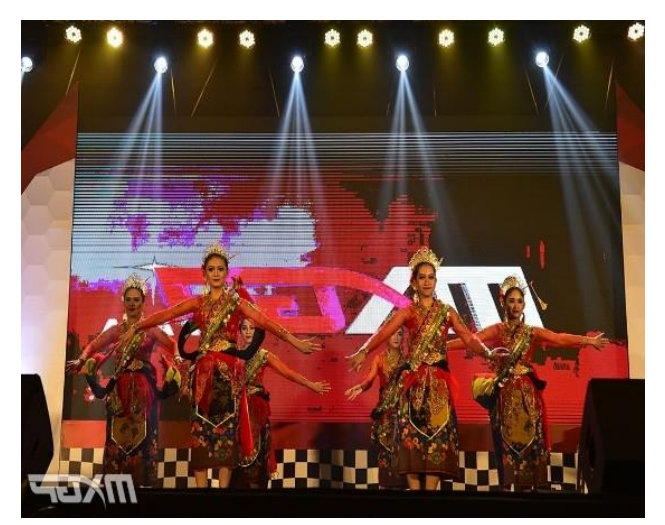

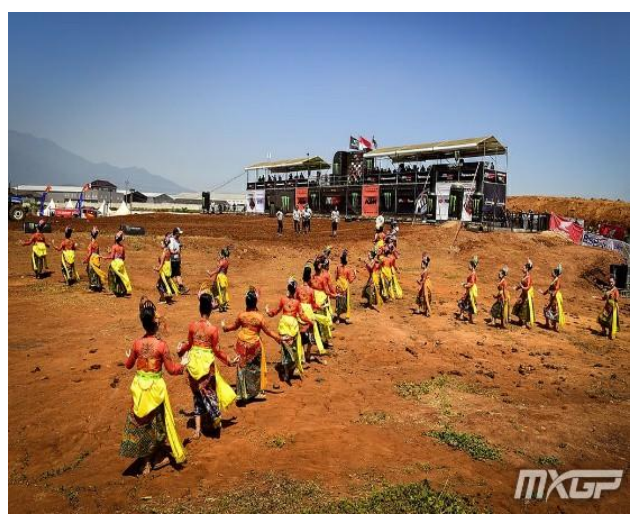

Figure 2. Cultural dance performance during opening ceremony Source: Official MXGP, 2019
Cultural dances show Indonesian cultural richness and attract foreign tourists including world racers taking part in the tournament. The event was opened by Youthstream and the Semarang Mayor as shown in Figure 3. 


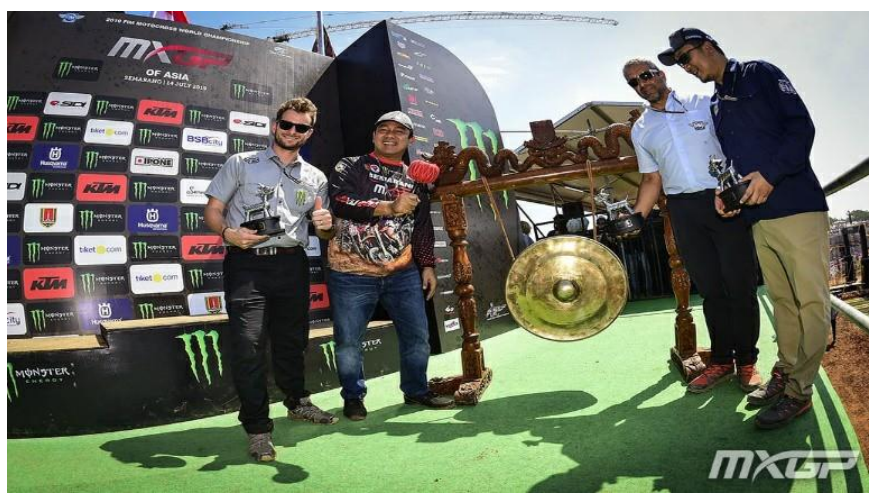

Figure 3. Opening Ceremony of Motocross MXG Tournament, 2019. Source: Official MXGP

The event's organizer also provided comfortable seats for spectators in the hope that the event will become unforgettable experience. They must build fast access to the circuit arena of the MXGP tournament, as well as to the food and beverage court to increase consumption, bearing in mind that foods and beverages help create positive experience (Kim et al., 2015). The various facilities must be accessible and prepared with high standards. In addition, to create a positive atmosphere, the event manager also holds a fan meeting session, and provides a signature poster as a form of communication between racers and spectators in Paddock (Cevik Huseyin and Kerem Yildurum Simsek, 2020).

In general, the above condition serves as an opportunity for urban economic growth and development, particularly to increase income and job opportunities, minimize inflation (Homafar et al., 2011) and improve city and/or state image (Kim et al., 2015).

The research conducted by Liu and Gratton (2010) affirm that all image factors serve as a prediction of intention to visit again the destination. Awareness of sport will have an impact on the atmosphere and image of destination services, as well as the image of tourist destinations (Liu \& Gratton, 2010). In the motocross MXGP tournament, a series of events take place in different time, including coaching, rating race, first race, second race, and award ceremony. Spectators spent long time in the event area while watching racing attractions (Figure 4 and Figure 5).
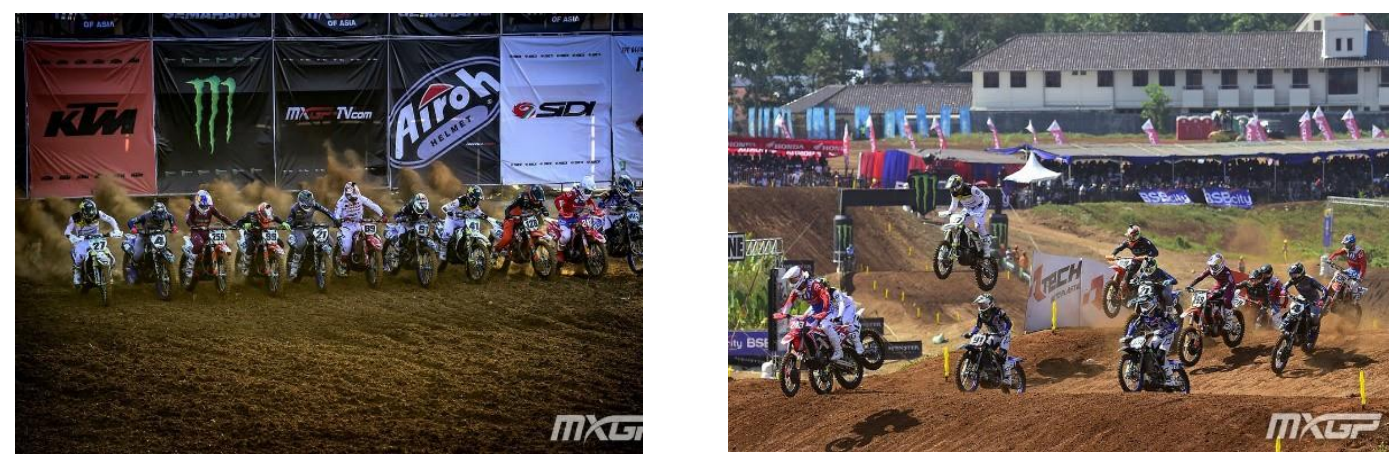

Figure 4: Racing attractions in motocross MXGP tournament Source: Official MXGP 2019

Semarang has relatively succeeded in luring sport tourists, who can eventually affect the perception and opinion of tourists about the image of tourist destination. Foreign tourists who took part in the motocross MXGP world championship 2019 came from Malaysia, Singapore, Austria, Germany, France, Japan, Australia, India, the United States, Italy and the Netherlands. In total, about 2,000 foreign tourists watched the motocross world championship (Informant HN, 2020).
Chalip \& Green (2003), in their research, stated that the economic effect of a large event hinges on marketing communication and news coverage during the event and various interesting attractions for participants and spectators Chalip \& Green, 2003. The Semarang Mayor estimated the number of spectators on the circuit at 60,000 (an interview, October 9, 2020). 


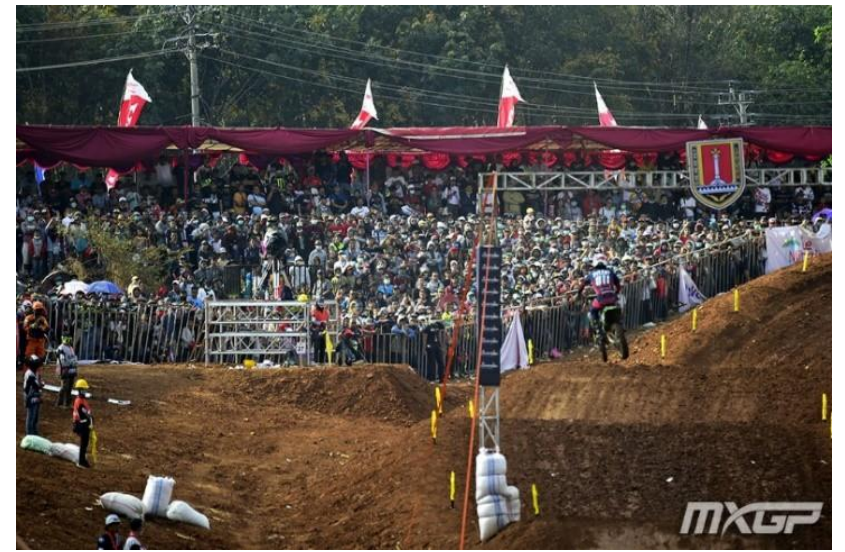

Figure 5. Spectators in the motocross MXGP world championship Source : (Official MXGP, 2019)

If tourists are satisfied with an event, they will come again to watch a similar event. This makes it possible to build long-term relations and develop eternal relations between the event and spectators, which will at the end strengthen the potential of the event's organizer to reach consumers. One of the most effective ways to reach new consumers is mouth-to-mouth promotion. Mouth-to-mouth promotion is $700 \%$ more effective than ads in newspapers, $400 \%$ more than private sales, and $200 \%$ more than radio ads (Severt et al., 2007). Pine \& Gilmore (1998) revealed marketing through experiences is more important than ads because consumers will convey their positive experiences and perception to other people (Pine \& Gilmore, 1998).

In this connection, the IMI Chairman stated "Semarang City is crowned as an organizer with the best promotion in the world". In an interview, Semarang Mayor Hendrar Prihadi revealed the influx of spectators was caused by the promotion conducted in up to 126 countries (an interview, September 30, 2020). Infront Moto Racing CEO said in an interview:

the promotion for this event in Semarang, I have never seen this type of promotion in Europe, but we want this. It is a huge investment in time and people to make the track and the paddock and you have to respect these organizers outside of Europe.

\section{Conclusions}

Semarang is relatively successful in attracting about 60,000 foreign and domestic tourists by organizing a large scale sport event. The success makes Semarang well-known as the host of good motocross world championship. The success also has given positive contributions to Semarang City in terms of opportunities to increase economic growth and urban development, raise income and job opportunities, minimize inflation and promote city image.

The use of sport event as a strategy of building brand has successfully improved city image through sport tourist destination, as is evident from the city having twice hosted the motocross world championship. The success to host the motocross world championship has influenced the perception, choice, behavior and satisfaction of customers, investors or visitors in watching the automotive sport event.

\section{References}

Astuti, M. T. (2015). Potensi Wisata Olahraga Dalam Meningkatkan Kunjungan Wisatawan. Jurnal Kepariwisataan Indonesia, 10(1), 3140.

Cevik, H., Kerem, Y.S. (2020). The effect of event experience quality on the satisfaction and behavioral intentions of motocross World Championship spectators. International Journal of Sports Marketing and Sponsorship, 21(2), 389-408. https://doi.org/10.1108/IJSMS-05-2019-0052

Chi, C. G. Q., \& Qu, H. (2008). Examining the structural relationships of destination image, tourist satisfaction and destination loyalty: An integrated approach. Tourism Management, 29(4), 624-636. https://doi.org/10.1016/j.tourman.2007.06.00 7

Couto, U. S., Lai Tang, W. S., \& Boyce, P. (2017). What makes a motorsports event enjoyable? The case of Macau Grand Prix. Journal of Convention and Event Tourism, 18(1), 26-40. https://doi.org/10.1080/15470148.2016.1207 121

Dongfeng, L. (2013). Major sports events, destination image and intention to revisit from the foreign tourist's perspective. International Journal of Sports Marketing and Sponsorship, 14(3), 23-34. https://doi.org/10.1108/ijsms- 
14-03-2013-b003

Gibson, H. J., Lamont, M., Kennelly, M., \& Buning, R. J. (2018). Introduction to the Special Issue Active Sport Tourism. Journal of Sport and Tourism, 22(2), 83-91. https://doi.org/10.1080/14775085.2018.1466 350

Goeldner, C. R., \& Ritchie, J. R. B. (2005). Tourism: Principles, Practices and Philosophies. In John Wiley \& Sons, Inc., Hoboken, New Jersey. https://www.entornoturistico.com/wpcontent/uploads/2018/04/Tourism-PrinciplesPractices-Philosophies.pdf

Hanif, A., Kusumawati, A., \& Mawardi, M. (2016). Pengaruh Citra Destinasi terhadap Kepuasan Wisatawan Serta Dampaknya Tterhadap Loyalitas Wisatawan (Studi pada Wisatawan Nusantara yang Berkunjung ke Kota Batu). Jurnal Administrasi Bisnis S1 Universitas Brawijaya, 38(1), 44-52.

Homafar, F., Honari, H., Heidary, A., Heidary, T., \& Emami, A. (2011). The role of sport tourism in employment, income and economic development. Journal of Hospitality Management and Tourism, 2(3), 34-37.

Hua, K. P., Chiu, L. K., \& Radzuwan, R. (2019). The Sports Event's Quality Towards Attendance Of Tourists At Sports Event Hosted At Northern Zone Of Malaysia. Journal of Academia, 7(1), 126-132. https://nsembilan.uitm.edu.my/joacns/images /v7_SI/pdf/A14_KhorPoy_126_132.pdf

Irawan, F. (2019). Hingga Desember 2019, Indonesia Miliki 17.491 Pulau: Okezone Economy.

Okefinance. https://economy.okezone.com/read/2020/02/1 0/470/2166263/hingga-desember-2019indonesia-miliki-17-491-pulau

Jin, N. (Paul), Lee, H., \& Lee, S. (2013). Event Quality, Perceived Value, Destination Image, and Behavioral Intention of Sports Events: The Case of the IAAF World Championship, Daegu, 2011. Asia Pacific Journal of Tourism Research, 18(8), 849-864. https://doi.org/10.1080/10941665.2012.7113 36

Kim, W., Jun, H. M., Walker, M., \& Drane, D. (2015). Evaluating the perceived social impacts of hosting large-scale sport tourism events: SCALE development and validation. Tourism Management, 48, 21-32. https://doi.org/10.1016/j.tourman.2014.10.01 5

Liu, D., \& Gratton, C. (2010). The impact of mega sporting events on live spectators' images of a host city: A case study of the Shanghai F1
Grand Prix. Tourism Economics, 16(3), 629-

645.

https://doi.org/10.5367/00000001079227834 7

Martins, M. (2015). The tourist Imagery, the Destination Image and the Brand Image. Journal of Tourism and Hospitality Management, $\quad 3(2), \quad 1-14$. https://doi.org/10.15640/jthm.v3n2a1

Mico, D. (2019). Ini Alasan Kuat, Kenapa

Semarang Terpilih Lagi Selenggarakan MXGP - Kilasdaerah.kompas.com. Kompas.Com.

https://kilasdaerah.kompas.com/semarang/rea d/2019/07/05/09252881/ini-alasan-kuat-

kenapa-semarang-terpilih-lagi-

selenggarakan-mxgp

Moilanen, T., \& Rainisto, S. (2009). How to Brand Nations. In Cities and Destinations. Houndmills: Palgrave.

MXGP GUIDE. (2019). The, Guide of Championship, 2019 Fim Motocross World. 187.

file://C:/Users/HP/Downloads/MXGP_Offic ial_Guide_2019_LD.pdf

Pike, S., \& Ryan, C. (2004). Destination positioning analysis through a comparison of cognitive, affective, and conative perceptions. Journal of Travel Research, 42(4), 333-342. https://doi.org/10.1177/0047287504263029

Pine, B. J., \& Gilmore, J. H. (1998). Welcome to the experience economy. Harvard Business Review, 76(4), 97-105.

Pratiwi, S. R., Dida, S., \& Sjafirah, N. A. (2018). Strategi Komunikasi dalam Membangun Awareness Wisata Halal di Kota Bandung. Jurnal Kajian Komunikasi, 6(1), 78. https://doi.org/10.24198/jkk.v6i1.12985

Qu, H., Kim, L. H., \& Im, H. H. (2011). A model of destination branding: Integrating the concepts of the branding and destination image. Tourism Management, 32(3), 465476. https://doi.org/10.1016/j.tourman.2010.03.01 4

Severt, D., Wang, Y., Chen, P. J., \& Breiter, D. (2007). Examining the motivation, perceived performance, and behavioral intentions of convention attendees: Evidence from a regional conference. Tourism Management, $28(2)$, 399-408. https://doi.org/10.1016/j.tourman.2006.04.00 3

Sunarto, H. (2020). Strategi Branding Pengembangan Industri Pariwisata 4.0 melalui Kompetitif Multimedia di Era Digital. Journal of Tourism and Creativity, 4(1), 1-20. 
UNWTO. (2020). Sports Tourism | UNWTO. UNWATO. https://Www.unwto.org/sporttourism

Watanabe, Y., Gilbert, C., Aman, M. S., \& Zhang, J. J. (2018). Attracting international spectators to a sport event held in Asia: The case of Formula One Petronas Malaysia Grand Prix. International Journal of Sports Marketing and Sponsorship, 19(2), 194-216. https://doi.org/10.1108/IJSMS-08-2017-0077 Youthstream. (2019). MXGP of Indonesia and MXGP of Asia Get Ready for 2019 | MXGP. MxGP.Com.

https://www.mxgp.com/motocross/news/mxg p-indonesia-and-mxgp-asia-get-ready-2019 